\title{
The problem of money in the hand of a fool
}

\begin{abstract}
Author:
James Alfred Loader ${ }^{1,2,3,4}$

Affiliations:

${ }^{1}$ Faculty of Theology,

University of Vienna, Austria

${ }^{2}$ Department of Old

Testament and Ancient Near

Eastern Studies, University of

South Africa, South Africa

${ }^{3}$ Department of Ancient Languages and Cultures,

University of Pretoria,

South Africa

${ }^{4}$ Faculty of Theology,

University of Pretoria,

South Africa

\section{Correspondence to:}

James Alfred Loader

Email:

james-alfred.loader@univie.

ac.at

Postal address:

Schenkenstrasse 8-10,

A-1010 Vienna, Austria

Dates:

Received: 28 May 2012

Accepted: 06 July 2012

Published: 15 Oct. 2012

How to cite this article: Loader, J.A., 2012, 'The problem of money in the hand of a fool', HTS Teologiese Studies/ Theological Studies 68(1), Art. \#1266, 9 pages. http:// dx.doi.org/10.4102/hts. v68i1.1266
\end{abstract}

C 2012. The Authors. Licensee: AOSIS OpenJournals. This work is licensed under the Creative Commons Attribution License.
This article focused on a single proverb, viz. Proverbs 17:16. The syntax and stylistic features were analysed to demonstrate the extreme polyvalence that can characterise terse aphorisms. Fifteen readings were examined and evaluated, resulting in the distillation of four equally valid clusters of meaning. This informed the argument that the terseness of aphorisms is conducive to multiple legitimate interpretations which constitute the 'readings'. The implications were considered in terms of intentionality and text-immanence in detailed exegesis. It was concluded that a combination of sophisticated linguistics and stylistic sensitivity in proverb exegesis can, in the sense of Herderian and Gunkelian 'Einfühlung' in minutiae, uncover a richness in ostensibly simple texts - which is to be distinguished from traditional methods claiming to probe 'under the surface'.

\section{Introduction}

A cursory reading of Proverbs 17:16 is sufficient to impress upon the reader the gravity of its content and at the same time the humour by means of which serious matters can be expressed and even enhanced. This can readily be seen in an unmarked literal rendering of the line (to avoid pre-empting some of the possible interpretations): 'why this a fee in the hand of a fool to buy wisdom and a heart not there.'

Whatever the precise meaning may be, the fact that the line begins with the interrogative למה makes it obvious that it contains a question. It is also clear that the acquisition of wisdom is the main topic that the question is about. Even a superficial familiarity with the Book of Proverbs would suffice to realise that this is just about the most serious thing that can be found in the anthology. ${ }^{1}$ Of whatever type the question may be, it contains a topic from the very core of the book's concern. Moreover, anyone who has read only a few chapters of the book of which the line is part, can also recognise the presence of a cluster of words so characteristic of sapiential literature ${ }^{2}$ that the degree of earnestness in the line can easily be sensed.

But we also hear something funny. The question does not suggest an obvious sapiential answer such as the following question does (Pr 5:20): 'Why should you be dazed, my son, by a strange woman or embrace the bosom of an adulteress?'

Here the intended answer is obviously: 'For no reason at all, dad!' But whoever asks what reason might lurk behind a fool's endeavour to buy wisdom, does not suggest an evident answer to the listener. Foolish shopping for the opposite of foolishness is just too absurd to avoid the initial reaction of a chuckle. But if the absurdity of the little picture also carries an earnest overtone, the line cannot merely be frivolous. So there is all the more reason to look deeper.

\section{Proverbs 17:16}

We shall now first consider the syntactical constituents with which the line is built up and then take a look at the poetic divisions of the stich and its hemistichs, which would enable us to consider some implications.

\section{The text and its modern translators}

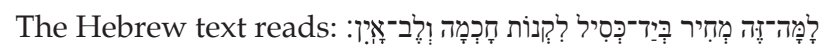

1.Cf. the introduction, where its relationship to faith in Yahweh is underlined (Pr 1:1-7), and the repeated insistence on the importance for young boys to acquire wisdom (e.g. $\operatorname{Pr} 2: 1-7 ; 3: 1-2$ ) as the most valuable asset thinkable (e.g. $\operatorname{Pr} 4: 7)$.

2.The terminology consists of: 'wisdom' (דכמה), 'fool' (כסיל), 'heart' (לב), and the motif of a lacking heart (Pr 6:32; 7:7; 9:4, 16; 10:13; $11: 12 ; 12: 11 ; 15: 21 ; 17: 18 ; 24: 30)$. 
There are multiple ways in which this can be translated: ${ }^{3}$

1. Why then is there purchase-money in the fool's hand to buy wisdom, since he has no understanding? ${ }^{4}$

2. What is the use of purchase-money in the hand of the self-contented to buy wisdom? Where there is no understanding! ${ }^{5}$

3. Why is this money in the hand of a fool to purchase wisdom when he has no mind? ${ }^{6}$

4. For what purpose the price in the hand of a fool to buy wisdom when there is no heart for it? ${ }^{7}$

5. What's the point of a payment in a dolt's hand to buy wisdom, when he lacks a mind? ${ }^{8}$

6. Why is there a fee in the hand of the fool to buy wisdom when he has no sense? ${ }^{9}$

7. Why in the world is there payment in the hand of a fool to buy wisdom when he has no capacity to learn? ${ }^{10}$

8. If the fool has money to buy wisdom, what boots it, since he has no mind? ${ }^{11}$

9. Of what avail is there a price in the fool's hand to buy wisdom, and intellect there is none?

10. What good does it do a fool to come fee in hand to buy wisdom when he has no mind? ${ }^{12}$

11. Why then does the fool have a fee in his hand? To buy wisdom when he has no brains? ${ }^{13}$

12. Why then is there money in the hand of fools? (Perhaps) tobuy wisdom and he has no understanding? ${ }^{14}$

13. Why then is there money in the fool's hand - (perhaps) to buy wisdom if he has no understanding? ${ }^{15}$

14. Why then is there money in the fool's hand, (perhaps) to buy wisdom where there is no understanding? ${ }^{16}$

15. Why is this, that there is purchase-money in the hand of a fool? - To buy wisdom, since he has no mind!

3.I have tried to render the German translations of the Hebrew as closely as possible in English and have inserted these in square brackets together with the references in the appropriate footnotes.

4.Delitzsch (1873:283): 'Wozu doch Kaufgeld in des Thoren Hand um Weisheit zu erwerben, da er doch kein Herz hat?.'

5.Meinhold (1991:290): 'Was soll denn der Kaufpreis in der Hand des Selbstzufriedenen, um Weisheit zu erwerben? Wo kein Verstand vorhanden ist!'

6.Clifford (1999:163).

7.Murphy (1998:126).

8.Fox (2009:632).

9.Alter (2010:268).

10.Waltke (2005:44)

11.Toy (1914:346). This is Toy's paraphrase of his own literal translation. I give his literal translation under no. 9.

12.Scott (1981:109)

13.McKane (1977:237).

14.Plöger (1984:198): 'Wozu denn Geld in der Hand der Toren? Um Weisheit zu erwerben und inm fehlt der Verstand?'

15.Sæb $\varnothing$ (2012:230): 'Wozu denn Geld in des Toren Hand - um Weisheit zu erwerben wenn ihm Verstand fehlt?'

16.Gemser (1963:72): 'Wozu denn Geld in des Toren Hand, um Weisheit zu kaufen, wo kein Verstand?

\section{Different accounts for different readings}

Depending on how the syntax of the line is handled, these renderings can be divided into three groups. Numbers 1-10 are readings of the line as a single question (with the exception of Number 2, which nevertheless belongs to the group). Numbers 11-14 read it as two separate questions. Number 15 reads it as a question followed by an answer. I could not find any in-depth analysis of the syntactic constituents to undergird the readings presented here, not even in the usually very thorough commentary by Bruce Waltke, who is an acknowledged expert on Hebrew grammar and syntax, or in the highly analytic monograph on the poetics of short proverbs by Jürg Luchsinger (2010), who skips the verse.

\section{Franz Delitzsch}

However, in his famous 19th-century commentary Franz Delitzsch (1873) pays attention to the divisions within the verse via the Masoretic accentuation signs:

With $\pi$ the question is sharpened, therefore, not: To what end is there purchase-money . .? Perhaps to buy wisdom? - the

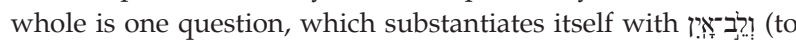
be thus accentuated when Mugrasch precedes). [At the end of his parenthesis Delitzsch adds a footnote:] When one writes וְל with

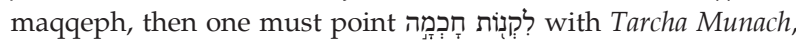
because the silluq-word does not have two syllables before the tone when written like this. This combination of accents is found in Vened. 1521. 1615. Basel 1619, whereas most editions have

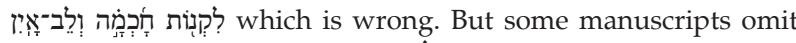

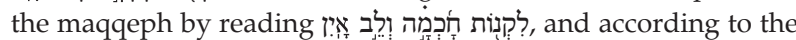
maqqeph rules of the metric accentuation system that is correct, see Thorath Emeth p. $40 .{ }^{17}$ (p. 283)

Delitzsch considers the whole stich as one question with built-in substantiation at the end. In support, he eliminates the maqqeph between the last two words and points them with the conjunctive munah and silluq (ולבב אין), which in turn makes it necessary to point the words 'to buy wisdom'

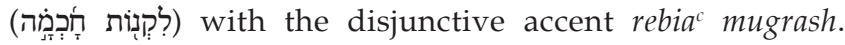
Delitzsch is saying that 'and there is no heart' is to be loosened from 'to buy wisdom', which in turn is more closely bound to the first half of the verse:

Why then is there purchase-money in the fool's hand to buy wisdom,

and there is no heart?

He says that this pointing, which he regards as 'the correct one', is attested in some manuscripts, but does not identify them. The reading that would be wrong according to the rules for the use of the maqqeph (retaining both maqqeph and rebiac mugrash), is found in several printed editions, which Delitzsch also does not identify. He then reconstructs what

17.'Mit TI wird die Frage geschärft, also nicht: Wozu das Kaufgeld da . .? Etwa Weisheit zu erwerben? - das Ganze ist eine Frage, die sich selbst mit ולוץ (so mit vorausgehendem Mugrasch ist zu accentuiren) begrundet. The printing of the signs is difficult to read.Delitzsch's Footnote: 'Schreibt man וְֵַ mit Makkef, so hat

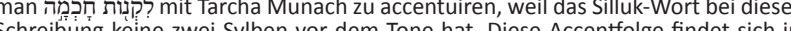
Schreibung keine zwei Sylben vor dem Tone hat. Diese Accentfolge findet sich in

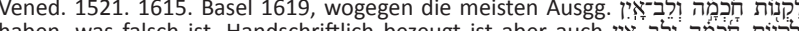

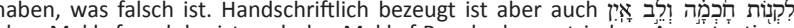
ohne Makkef, und das ist nach den Makkef-Regeln des metrischen Accentuationssystems das Rechte, s. Thorath Emeth p. 40.' 
the pointing should be if maqqeph is to be retained: (with tarha and munah). Although Delitzsch does not refer to any source for this reading and offers it as a reconstruction for what would be necessary to retain the maqqeph at the end of the verse, this is also the reading found in the Codex Leningradensis 19B, followed by Biblia Hebraica Stuttgartensia and Biblia Hebraica Quinta. Now munah with tarha represents a closer clustering of the last four words and a stricter consideration of the atnah in the middle of the verse. Delitzsch softens the caesura in the middle by opting for the alternative pointing and therefore by disjoining 'to buy wisdom' from 'and there is no heart', which enables him to read the whole line as one question.

Delitzsch does not pay as much attention to the stylistic features of the verse. To be sure, the Masoretic considerations do not separate strictly between linguistic and stylistic issues and Delitzsch does indirectly address or imply some of them because he uses the Masoretic pointing tradition as his orientation. He does not consider the impact of softening the atnah in the middle of the verse. This is also a Masoretic sign and marks a reading with the main caesura exactly in the metric middle of the verse as pointed in L 19B. Accounting for his own reading, Delitzsch does not follow the Leningrad line, but independently opts for his own, even at the expense of the strong divider atnah - which can only be done by a reader as erudite in the details of the Hebrew text as Delitzsch. Moreover, by his syntactical forging of the whole line into a single question with circumstantial clause, the poetic units become unconventional. Either a metric pattern of $5+2$ (which is irregular) or of $3+2+2$ (which is also unconventional) would have to be assumed. A metrical arrangement of $4+3$ (which is normal in sapiential literature) would not be possible on Delitzsch's submission, because of the disjunction

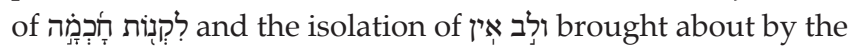
reconstruction of accents and elimination of maqqeph. It may be that Delitzsch deliberately opted for a reading that makes an off-beat Qohelet-like metre necessary in a verse that could also be read with a smooth metre. His reading is not only possible, but could also combine a bumpy metre with a bumpy content as Qohelet does. Whether or not Delitzsch intended it, that is what he in fact has done.

As for the style, the question posed in the verse is clearly rhetorical for Delitzsch, since it implies the answer, 'to no avail'. Approaching the constituents of the poetic verse via the Masoretic pointing, Delitzsch also takes a stand on the syntax. The last phrase ('and there is no heart') becomes a circumstantial clause embedded into a question. The verse would then rhetorically ask why - the circumstances being that the fool has no heart/mind - such a person has purchase-money in hand. According to Delitzsch's reading the meaning is then: In circumstances where the heart/ mind as the precondition for wisdom is lacking, no effort to acquire it has any sense, not even for a fee. This reading remains open to the possibility that education fees existed and could be expected at the time of the proverb's origin, which is reinforced by the fact that Delitzsch explicitly refers to Proverbs 4:5, 7, where the young pupil is advised to 'acquire' wisdom and understanding (קנה the same verb as here, is used) and that he should be willing to pay any price (כל־קנינך) for it. The point is therefore not so much that wisdom cannot be bought for money, but that it cannot be acquired at all (even with money) if the basic prerequisite, the understanding faculty of the heart, is not there. Any endeavour to attain wisdom is rendered futile by low intelligence.

\section{Arndt Meinhold}

Although the translation by Arndt Meinhold is not backed up by linguistic or stylistic argument, he has made decisions in these fields. He divides his translation into two hemistichs, but ends the question beginning in the first hemistich in the middle of the last. ${ }^{18}$ Then follows a second sentence, which according to Meinhold is an exclamation. So we have the following pattern:

What is the use of purchase-money in the hand of the selfcontented to buy wisdom?

Where there is no understanding!

That 'fool' (כסיל) is here taken to be the self-contented person, is not of primary importance for our present purpose. But the translation of 'why?' (למה) as 'what is the use' makes it clear that Meinhold takes the first section as a rhetorical question implying a negative answer, namely that it is of no use. The second sentence is then an exclamation of the reason why the question should be understood as a statement with negative effect, viz. that the faculty of understanding is lacking in the mental make-up of such a person.

But Meinhold's breakdown of the poetical structure differs from his syntactical pattern:

What is the use of purchase-money in the hand of the selfcontented

$$
+
$$

to buy wisdom? Where there is no understanding!

Although he mentions neither the metrical pattern nor the power of the atnah nor the use of disjunctives and conjunctives, his arrangement of the hemistichs respects the caesura in the verse middle despite his syntactical breakdown, which softens the caesura. The result is an enjambment of hemistichs superimposed on the syntactical substructure. Although this is possible, such a combination causes the syntax and the rhythmic organisation to stand in tension. The reader could find this an appropriate representation of the tension between the fool's desire to buy wisdom and the impossibility for him to do so. An inept form, so to speak, is employed to mimic the very ineptitudo quaerens intellectum it discusses.

So the sense of the verse is very like that proposed by Delitzsch: Where understanding as the first requirement for its acquisition is not present, wisdom cannot be come by.

18.The fact that Meinhold has a comma at the end of the first hemistich ( ${ }^{. .}$ Selbstzufriedenen, ...') says nothing, since it is compulsory in German orthography before a final clause beginning with ' $u m^{\prime}$ ' 
This, again, assumes that one is not born wise and must acquire wisdom. But one is born either with or without the capacity to attain it. Although this, and not the stupidity of imagining that wisdom can be had for money, is the basic issue in Meinhold's reading, he does see another question highlighted by the motif of money. It may 'perhaps' be that the fool also thinks money can get him wisdom, but Meinhold finds the motif interesting since it raises the question of tuition fees in ancient Israel. Since Micah 3:11 seems to scorn the idea of information for money, the tuition fee idea seems to Meinhold (1991:291) rather unlikely. But this is rather a question posed by historical research and not by the organisation of the proverb (to which, in any event, it could be retorted that the mere fact that the idea is frowned upon by a critical prophetic text can suggest that precisely that which is criticised was practiced).

For our purpose the interesting thing is that Delitzsch and Meinhold, although both place 'to buy wisdom' in the first syntactical unit, differ in that the former sees one question and the latter a question plus an exclamation in the verse. Their different approaches notwithstanding, they arrive at a comparable meaning for the thrust of the proverb as a whole.

\section{Richard Clifford}

The third one-sentence reading is that given by Clifford. His breakdown is different once again. Like Delitzsch, he takes the whole verse as one question, and unlike Meinhold he takes 'and there is no heart' as a circumstantial clause (or an adverbial clause of time, which is formally possible but unlikely in the context) and not as a separate sentence. Syntactically there is only one block:

Why is this money in the hand of a fool to purchase wisdom when he has no mind?

But unlike Delitzsch and like Meinhold, he does not soften the atnah, so that the verse organisation in hemistichs also results in an enjambment:

Why is this money in the hand of a fool $+$

to purchase wisdom when he has no mind?

Although his syntax has affinities with Delitzsch and his enjambment is not unlike that in Meinhold's reading, he follows quite another route to arrive at the meaning of the verse. On the grounds of such injunctions as Proverbs 4:5 and others, he reads the verb קנה ['buy'] not as literally 'purchase', but as a metaphor playing with the concept of a business transaction and meaning to 'attain' wisdom. ${ }^{19}$ But the fool misunderstands the metaphor and tries to literally buy wisdom with real money (Clifford 1999:166). This in

19.Clifford seems to be dependent on Gemser (1963:73). Therefore the other texts to which he refers are probably Proverbs 4:7 and 23:23, also mentioned by Gemser. Especially Proverbs 23:23 is interesting, since the injunction there is that wisdom discipline and insight are to be bought (קנה) together with truth - and not sold (מכר) again. Even if it is meant metaphorically, as Gemser surmises ('wohl' = 'probably', not 'certainly'), it would still assume that paying for wisdom is a quite thinkable not 'certainly'), it would still assume that paying for wisdom is a quite thinkable concept, so much so that the sage expects it to be understood as an image to explain what he means. As with Proverbs 4:5, 7, the question would still remain: one acquires wisdom with all one's possessions and does not dispose of it again how can one do so if not in a pecuniary way? Therefore the suggestion made by Oesterley (1929.142), 'this seems to imply that a fee was paid by those who went to the sages for instruction', is not so easily disposed of by merely claiming with Gemser (1963:73) that it 'does not suggest itself' ('liegt nicht nahe'). itself shows that the fool has no mind and therefore cannot keep the wisdom which he has bought. It would perhaps be better to formulate: which he thinks to have bought, for, even if he has paid real money and has received real instruction, no wisdom results from the enterprise so that it cannot be said that he really bought wisdom. Clifford's reading may seem simple on the surface, but for these reasons it actually evokes a complex of logical implications, somewhat like Marcel Duchamp's 'Bicycle Wheel' from 1913, and may even be called a solipsism of sorts. ${ }^{20}$ So the very fact that somebody arrives with money for wisdom proves that person's inability to become wise, even after having been given it.

This is a combination of the motif of the futility of the attempt at wisdom by means of money and the motif that certain people do not have the capacity for wisdom. In this case, the fool's inability is apparent ex post facto. But that denies the possibility of school fees. If willingness to pay for wisdom constitutes proof of the inability to attain wisdom, then payment could not have been part of sapiential practise. ${ }^{21}$

\section{Roland Murphy}

Murphy construes basically the same combination of syntactic and poetic patterns as Clifford. The last half of the second hemistich is read as a circumstantial clause that proves the basis for the rhetorical question:

For what purpose the price in the hand of a fool to buy wisdom when there is no heart for it?

Again the syntax leads to an enjambment of two stichs. Although Murphy does not comment on it, it seems that he reads the verse according to the pointing in L 19B, notably with two hemistichs metrically organised as 3+3:

For what purpose the price in the hand of a fool

to buy wisdom when there is no heart for it?

According to Murphy (1998) the meaning of the verse contains the stylistic device of irony, which means that the direction of its pointe is the opposite of the semantic thrust. That is certainly the case, but the way in which Murphy construes it, cannot be upheld: 'Even should he [the fool] possess the means to become wise, he will not employ them.' But that would deny the clear rhetorical implication that the fool does want to use his monetary means for buying wisdom. This is also implied by Murphy himself when he states that 'there is probably a sarcastic implication: the fool is dumb enough to think that the acquisition is merely a matter of monetary transaction.' Therefore Murphy declares the price to be 'only metaphorical' (Murphy 1998:130).

In trying to combine all of this, Murphy in my opinion undermines the potency he has noticed in the verse. Firstly, if the money is only metaphorical, the fool cannot be stupid enough to try to use real money. Secondly, the irony he has noticed cannot at the same time be sarcastic. Irony creates

20.For example: All buyers of wisdom are fools; therefore no buyers of wisdom have bought wisdom.

21.We shall return later to another possibility of understanding this motif; cf. my proposal under 15. below. 
a tension of opposites and sarcasm puts its intention in $1 / 1$ terms. But Murphy has alerted us to notice that the proverb can be read as irony and that it can also be read in another way, namely as sarcastic ridicule. Reading it as irony would mean the venture of the fool to acquire wisdom is an incorrigible venture of folly. Reading it as sarcasm however means that the fool's idea of wisdom on sale is ridiculous. This differs from Clifford's reading in that Clifford forges together the ideas of the hopelessness of fools and the noncommercial value of wisdom, while Murphy alerts the reader to two unrelated levels of meaning that can legitimately be found in the Hebrew text. These are either: a person lacking understanding is incorrigible, or: wisdom cannot be bought.

\section{Michael Fox}

Fox takes the verse as a single question with embedded circumstantial clause:

What's the point of a payment in a dolt's hand to buy wisdom, when he lacks a mind?

Poetically, the circumstantial clause makes up the last part of the second hemistich, while an infinitive purpose clause precedes it in the first part of the same hemistich:

What's the point of a payment in a dolt's hand $+$

to buy wisdom, when he lacks a mind?

Fox's contribution to the arsenal of possibilities is that he emphasises the fool's desire to obtain wisdom. This obliges the reader to consider what wisdom the dunce (as Fox calls him) craves. If it is sagacity and prudence, he would not be a fool but a פתי, an uneducated youth of the best sort. One could support this by pointing to the fact that naïve young men undergoing sapiential education are encouraged to strive after wisdom of this sort (cf. Pr 1:4; 2:1; 3:1; etc.). The money such a youth has in hand may also be to acquire (קנה) this kind of wisdom and understanding (בינה, Pr 4:5, 7; 23:23). However, this cannot be the case in our present proverb, since it is excluded by the term כסיל and explained by the circumstantial clause. The fool would rather wish to have the goodies that he perceives as the benefits of wisdom.

In this reading, neither the idea of a fool's incurability nor the un-commercial character of wisdom makes up the pointe of the verse. Without denying the negative aspects of a fool's mental make-up, the thrust of the rhetorical question would then be the futility of going after wisdom with ulterior motives.

\section{Robert Alter}

In Alter's case, the enjambic reading leads to yet another possibility:

Why is there a fee in the hand of the fool to buy wisdom when he has no sense?

The single sentence by which the question is constituted is presented in such a way that Alter, like Murphy, agrees with the pointing in L 19B. He does not use a comma to separate the circumstantial phrase from what precedes it, but he does present the verse as a bicolon:

Why is there a fee in the hand of the fool

$$
+
$$

to buy wisdom when he has no sense?
Alter's translation of למה־זה differs from the renderings by Murphy, Fox and others in that he does not suggest a rhetorical question. Neither does he exclude it, but by avoiding renderings like 'for what purpose?', 'what's the use?' (Fox) or 'why in the world?' (Waltke 2005) he keeps the question neutral. Accordingly, it can be an ordinary question formulating the problem that fools can be seen going around with money while, in terms of the nexus of deed or attitude and consequence fools are not supposed to have money. Why do they have wealth? Or it can indeed be a rhetorical question protesting at the incongruence between the retribution idea and reality. The fool should not have money to spend!22 In this case the implied statement of the rhetorical question would not be that fools think money can buy wisdom or that fools cannot attain wisdom, but that fools should have no money. It is therefore a problem for sapiential thinking that fools do have money and pushes the limits of conventional wisdom theory. On this count as well, the mere fact that it is perceived as a problem would suggest a reality in which it did happen that unintelligent people paid for tuition (whether in formal schools or not). It is therefore not surprising that Alter - whose notes to his excellent translation are offered very sparingly - is sympathetic to the inference that some sort of payment must have been made for instruction by sages (Alter 2010:268).

\section{Bruce Waltke}

Waltke also accepts the enjambic reading:

Why in the world is there payment in the hand of a fool $+$

to buy wisdom when he has no capacity to learn?

He paraphrases the למה question as 'why in the world' to express the exasperation of the speaking sage at the 'absurd situation' (Waltke 2005:56). However, he also moralises the issue raised by the statement of the rhetorical question by likening the money intended to buy wisdom with the money intended to acquire a prostitute. Waltke refers to Deuteronomy 23:18, but could also have invoked Proverbs $6: 26,7: 10$ or 29:3. It becomes plausible to make this connection in the light of the fact that erotic motifs are used in the Book of Proverbs to picture wisdom as a woman to be loved (e.g. $\operatorname{Pr} 4: 6 ; 8: 17)$ and to contrast her with Folly as a bad woman luring men by the wayside (Pr 9:13-18). Then the verse would be a rhetorical question with circumstantial clause to express exasperation at the idea that people could think of buying wisdom from a sage as one would buy sex from a prostitute.

\section{Crawford Toy}

The syntax of Toy's literal translation represents how he analyses the Hebrew text, which is like that of Waltke. However his added paraphrase reformulates it completely as a conditional clause with the protasis in the first half and the apodosis in the second half in the form of a rhetorical question to state the futility of the condition imagined by the protasis.

22.Cf. Proverbs 13:18 and the way in which Proverbs 10:2 tries to come to terms with the discrepancy; also the motif translated into pious terms in Psalm 37:1-2; 49; 73:12-20; for the problem as a whole, see Loader (2001:3-23). 
The literal translation would fit into two hemistichs:

Of what avail is there a price in the fool's hand to buy wisdom

$+$

and intellect there is none?

The paraphrase would also fit into two hemistichs, but completely transform the structure of the proverb:

If the fool has money to buy wisdom

$+$

What boots it, since he has no mind?

Toy interprets this as an antithesis going deeper than 'the golden proverb' of Democritus: 'There are many who have learning without mind (vov́v)' (Toy 1914:346). If the condition is met, it means nothing, for the rhetorical question expects the negative answer, 'nothing'. That excludes the fool from all wisdom. But it would also suggest a double answer to the theoretical problem of a fool's having wisdom at all. Firstly, it is only stated as a possibility, not as a reality, so that the harshness of the experience of the psalmists cited above is alleviated somewhat. But, secondly, the problem has not gone away; therefore the rhetorical apodosis provides it, claiming that money cannot buy what the fool thought it could. So, even if a fool could have the wish and the means to pay (which is problematic in its own right), that would also be worth nothing. The implied theodicy has taken place. One could therefore read the proverb as a statement questioning accepted mainstream views of deed and consequence (cf. Alter above), or one could read it as a smoothing out of the problem in terms of that same mainstream thinking. Toy does not develop this idea and only comments on the possibility that 'fees were taken by Jewish teachers' (which he finds doubtful). But he has alerted the reader to a possible interpretation.

\section{R.B.Y. Scott}

The last example of commentators who read the verse as one sentence is Scott's rendering of the rhetorical question in two completely disparate hemistichs. Syntactically, this is similar to several others that we have been examining above:

What good does it do a fool to come fee in hand to buy wisdom, when he has no mind?

But the breakdown into hemistichs is highly asymmetrical:

What good does it do a fool to come fee in hand to buy wisdom,

when he has no mind?

This assumes a metrical arrangement of $5+2$, which is highly irregular. It also supposes a rearrangement of the Masoretic pointing in three ways: The maqqeph between the last two words is to be eliminated, they are to be pointed with the conjunctive munah and silluq (ולב אין), and the words 'to buy

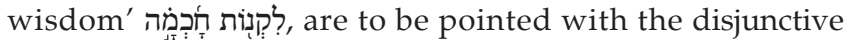
accent rebiac mugrash. But Scott - as opposed to Delitzsch (cf. above) - contemplates nothing of the sort. He does comment on the style and moves from there to the historical setting. According to him the verse is 'a sarcastic comment of a teacher dealing with refractory material' (Scott 1981:111). He reads that as proof that fees were indeed paid to wisdom teachers.
Without accounting for the stylistics of the verse, he provides a historical setting and reads the verse in that context. The sense would be: Some fathers' sons are just too stupid to justify the expense of education - somewhat like the present-day gibe to 'go and ask back your school fees!' Although Scott could be faulted for disregarding too many technical aspects of the text and although the tuition fee issue is controversial, it is a historical possibility and his reading of the gist of the verse is legitimate.

The readings of the following four scholars (11-14) approach the verse in the same way and stand over against the other readings considered so far. In all three cases the syntactical breakdown coincides with the scanning of the verse in two hemistichs as in L 19B and represented in the Biblia Hebraica Stuttgartensia and the Biblia Hebraica Quinta. They take the verse as two questions in two hemistichs.

\section{William McKane}

Why then does the fool have a fee in his hand? $+$

To buy wisdom when he has no brains?

The first is not a real rhetorical question, but rather a sharp-witted introduction to prepare a sarcastic comment in the second, which is a rhetorical question containing a circumstantial clause. McKane (1977:504-505) supports Oesterley (1929:142) as far as the hypothesis of tuition fees is concerned, and this impacts on his reading of the verse as two questions. He sketches the historical Sitz im Leben: A כסיל comes to a wisdom teacher with a fee, 'supposing that his money is an open sesame and his career as a sage assured.' This then evokes an observer's biting criticism in the form of two questions. The pointe is therefore not the incorrigibility of fools, but biting criticism of people who think tuition fees guarantee understanding.

\section{Otto Plöger}

Why then is there money in the hand of fools? $+$

(Perhaps) to buy wisdom and he has no understanding?

Plöger's syntax and metric reading are the same as McKane's. He does not take sides in the tuition fees debate, but does relate his interpretation to the possible historical situation. He points out that the verse can also be understood without recourse to a school situation (which, incidentally, can be squared with the careful formulation offered by McKane). In that case the fool is a 'snob' (as Plöger calls him) who thinks that money is a passport to wisdom. Plöger then goes a step further than McKane by finding the whole verse irony. Since the truly wise cannot even contemplate a כסיל wanting wisdom, it must be irony, saying that the wish to acquire quick wisdom and without the input of personal effort is real folly, which covers all other cracks at easy wisdom, including wanting to buy it. The questions then gravitate towards the statement: pupils who wish quick and easy wisdom are actually fools. 


\section{Magne Sæb $\varnothing$}

Why then is there money in the fool's hand $+$

(perhaps) to buy wisdom if he has no understanding?

Sæbø makes the last part of the last hemistich the protasis of a conditional clause ('wenn'). But this de facto has the same function as a circumstantial clause. Sæbø's commentary works with groups of verses according to related terminology and ideas, so that his very sketchy comment on Proverbs $17: 16$ is not readily noticed. But he does find the second hemistich to be an example that the fool is wise in his own eyes. He probably means that the idea of getting hold of wisdom quickly or specifically at a monetary price proves the complacency of folly. Since Sæbø explains so little, his presentation of the verse becomes more open. The logic goes yet another step further than Plöger and is unending: A fool needs wisdom $\rightarrow$ he tries to buy wisdom quickly $\rightarrow$ thereby showing that he really is a fool (= has no understanding) $\rightarrow$ he needs wisdom and so on all over. This would amount to a claim that fools can never acquire wisdom, since the foolish way of trying automatically leads back to square one. It is related to the readings of Clifford and Murphy, but arrives at its goal along a quite original and powerful way.

\section{Berend Gemser}

Apart from proposing a metaphorical understanding ${ }^{23}$ and doubting Oesterley's tuition fees hypothesis, Gemser offers no further comment on the verse. But his translation and the presentation of the stich organisation are quite illuminating. He also reads the verse in two clearly differentiated hemistichs, but the second one acquires yet another interpretive possibility.

Why then is there money in the fool's hand, $+$

(perhaps) to buy wisdom where there is no understanding?

There are two questions, but the second differs from the other proposals. Although not saying so, Gemser seems to take the conjunctive munah at חכמה together with the following waw as the indication of an adverbial clause of location. Does the fool try to buy wisdom where there is no understanding? That is, the second question is rhetorical, stating that the fool goes in search of wisdom where none is to be found. Since Gemser thinks the money is only a metaphor for any scheme to get quick wisdom, his reading suggests that a fool may try anywhere he likes, the only businesses that have his kind of commodity in stock are the ones who don't store real wisdom/ understanding. Gemser does not expound this reading, but his presentation has suggested it (to adapt his own terminology: nahelegen).

\section{My own proposal}

I would suggest that the verse be read as two sentences (visà-vis readings 1-10 above), but that these are respectively one real question and one direct answer in the form of a statement (vis-à-vis readings 11-14 above). The two sentences

23.Gemser (1963:73) uses the German term "bildhaft', which can either be understood to refer to metaphorical or, more vaguely, imaginary use of the idea of buying. coincide with the two hemistichs and are read with maqqeph

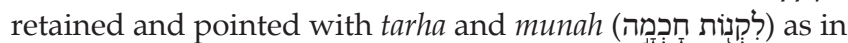
the Codex Leningradensis B19:

Why is this: purchase-money in the hand of a fool? -

To buy wisdom, since he has no mind!

This could be substantiated by elucidating the syntactical constituents of the verse. In the sketch below the accents are retained as they are in $B H S$ and $B H Q$.

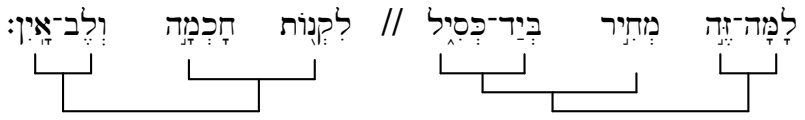

As far as I can see, most commentators neglect or even ignore the pronominal למה after. Delitzsch (1873:283) only claims that it 'sharpens the question', but neither accounts for this remark nor expands on it. The maqqeph plus the dagesh forte conjunctioum shows that this is a close unit. זה must have a referent, which can only be the fact of purchase-money (מחיר) in the hand of the fool (ביד־כסיל). The strongly unified 'why is this?' as such thus thematises a phenomenon. זידסיר, this thing (= phenomenon) pertains to 'purchase-money', which is qualified by the prepositional phrase 'in the hand of a fool'. Strictly speaking, it is possible to say that there are two sentences in the first hemistich (and therefore three sentences in the verse), namely two nominal sentences: [why is this?] and [purchase-money is in the hand of a fool]. However, according to the paratactic character of Hebrew syntax, the two nominal sentences construe one unit with a main clause ('why is this?') and a subject clause stating what the subject of the occurrence is. Therefore the question is: Why is the following phenomenon a fact? Why does it take place? The phenomenon is that a fool can be seen with money in his hand. The first hemistich thus presents a factual situation (casus) and questions the reason for it.

It follows that the answer must be given in the next hemistich. It is to buy wisdom, qualified by the circumstantial waw-clause, 'and he has no mind'. The circumstance of mindlessness qualifies the wish to buy wisdom and therefore explains it. In circumstances where people have no mind/ understanding, they try to buy it. But this is irony: it cannot be done, for a mindless person cannot become wise. The fool both tries a stupid thing and remains stupid for the trying. The irony takes the form of well-known stupidity gibes: [why this $]+$ [because that $].^{24}$

If a phenomenon is questioned, it is deemed problematic. Therefore an answer providing the reason behind the phenomenon is an effort to solve the problem. The problem is indeed huge. In terms of the nexus of deed and consequence, a fool should not have money. If he does, the foundations of the nexus (a principle that transcends the sapiential tradition, but is fundamental to it) become shaky. Can this

24.For example, Question: Why does the blonde (female) have cheese on her computer? Answer: To keep the mouse going. This could be transformed into the computer? Answer: To keep the mouse going. This could be transformed into the
topic of our proverb. Question: Why does the fool (masculine) have money in his topic of our proverb. Question: Why does the fool (masculing
hand? Answer: To give change at a penny for his thoughts. 
be explained? - Yes it can, and the proverb does so with the help of irony. Money in the hand of a fool is only there to lead to failure. Since he cannot get wisdom for money, he wastes the money and stays as mindless as ever. Therefore the deedconsequence-nexus is, after all, not so wobbly. ${ }^{25}$

\section{Conclusion}

This seemingly simple verse has provided a host of readings, all of them possible and viable from a linguistic as well as from a stylistic perspective. That is to say, the aphorism of the verse is highly polyvalent. In the work of fourteen authors we have found diverse ways of handling the text, sometimes more and sometimes less related to each other, delivering thirteen different readings of the text. These readings can in turn be grouped into four clusters pertaining to low intelligence, the demands of wisdom, moral fibre, and the limits of wisdom. According to these, the verse means:

\section{The hopelessness of low intelligence}

1. Efforts to attain wisdom are made futile by low intelligence (Delitzsch, Meinhold).

2. Those lacking understanding are incorrigible (Murphy).

3. Going after wisdom with ulterior motives is futile (Fox).

4. Some fathers' sons are just too stupid to justify the expense of education (Scott).

5. A combination of the futility of attempts at wisdom by means of money and the motif that certain people do not have the capacity for wisdom (Clifford).

\section{No easy way to wisdom}

6. Biting criticism of the idea that tuition fees guarantee understanding (McKane).

7. Pupils who wish quick and easy wisdom are actually fools (Plöger).

8. The foolish way to try for wisdom automatically leads back to square one (Sæbø).

9. The only businesses that trade this kind of commodity are those without real wisdom (Gemser).

\section{A moralist reading}

10.Exasperation at trading wisdom from sages like sex from prostitutes (Waltke).

\section{Struggling with the limits of wisdom}

11.Pushing the limits of conventional wisdom (Alter).

12.Softening the struggle for theodicy by the fact that the scenario is only a possibility (Toy).

13.Saving the sapiential doctrine similarly to the efforts of Psalms 37, 49, 73 (Loader).

25.I thank Dr. Reina-Marie Loader (Exeter) for pointing out a completely different reading (the fourteenth!) on the basis of my analysis of the verse as question and answer. Checking my manuscript, she commented that it would be possible to read the text against the intentio textus. For example, read in the context of the current controversy over tuition fees in British universities, one could de-demonise the foo and demonise the receiver of the fee: Why is there money in the hand of a fool? To buy wisdom (from us sages) because he is a dupe (who is willing to part with his money). This reading sees the fool (כסיל) as a naïve person (פתי) who is called stupid from the perspective of the teacher, who in turn stands to profit from others' simplicity and calls them insulting names into the bargain. The sages themselves thought that wisdom is power ( $\operatorname{Pr} 24: 5)$ and were quite aware that money is power too $(\operatorname{Pr} 10: 15 ; 18: 11)$. Such a reading would be improbable from the perspective of the sapiential redaction, which would not be likely to admit that sages profit from teaching blockheads (but then, neither would university professors). Read against the grain of the text, it is certainly a valid deconstruction of wisdom as power of the establishment.
The readings embody my reconstruction of possible readings emanating from the way in which fourteen representative readers of Proverbs handle the text. They do not necessarily have to exclude each other and sometimes do have elements in common. All share the characteristic of humour, which shows - especially in the treatment of the troubling recognition of the threat to sapiential foundations - that humour is a very serious feature of style indeed.

We may ask what the author intended with this proverb. Some readers (e.g. McKane and Scott) do it explicitly, while others (like Alter) obviously steer clear of an intentional reading. This highlights the impact of the methodological issue of intentionality and text-immanence on detailed exegesis. But, although posing historical questions and providing an argument, McKane's reading remains inconclusive so that other readings are not excluded. But, although it cannot be proven as the 'correct' exposition of the author's intention, it could plausibly be that. At any rate, it is itself not disproven. The same goes for Alter, who also refers to the possibility of a historical setting and whose literary reading remains possible and sensible, or for Delitzsch, whose reconstruction of Masoretic pointing signs represent viable and real receptions of the text in later Jewish tradition. Therefore no certain answer as to the 'correct' reading can be given either on the basis of an intentional or a text-immanent reading. If so much remains inconclusive but sensible so that the readings presented can all be defended, we have in the proverb a multilevelled communication. Using Proverbs 16:26, J.G. Williams (1980:35-58) has illustrated how a proverb can be open to several interpretations at once. In Proverbs 17:16 this is exceptionally prominent. A multilevelled aphorism functions on multiple levels at the same time and is therefore polyvalent.

I would suggest that this is not at all surprising in aphorisms. The very terseness of aphorisms can explain much of the polyvalence. Because an aphorism is by definition short, it depends on pithiness to communicate effectively. A successful aphorism will therefore tend to involve its hearers or readers. It will prompt questions and, by the same token, answers to those questions. I submit that this is what we have in Proverbs 17:16. By its question(s) it evokes considered answers and therefore further questions as part of the process of consideration. The very terseness thus requires, or at the very least provides scope for open-ended formulations inducing further transformations on the part of the receiver. As Fox (2009:621) puts it: '[aphorisms] can radiate meaning in many directions at once.'

But they need readers to do this. And if those readers avail themselves of linguistic and literary as well as historical approaches, these can play a big role in uncovering the questions invited by the aphoristic nature. This could be seen in the readings considered above: linguistics and poetic stylistics as well as historical context all played their role in reaching these readings. 
A plea for thorough literary and historical dimensions to the methodology of aphoristic interpretation seems an almost necessary conclusion to the exercise we have done above. Just as the aphorisms themselves preclude one-dimensionalism, the method of their exegesis should preclude it. Grammar and syntax, stylistics and historical enquiry, including the reception-historical aspects such as the many Masoretic shapes of the text - all of these are necessary dimensions of interpretation. On the one hand, this should be clearly distinguished from a mixture of such methods on one level (as though historical analysis and stylistic inquiry pose the same questions to the text), which is totally different from independently subjecting the text to several ways of reading. On the other hand it should also be distinguished from allegorical and typological exegesis. ${ }^{26}$ Using sophisticated linguistics, stylistic sensitivity and a historical sense to retrieve the richness that can lie hidden under the surface of the text is vastly different from using the potency of the text as imagery for constructions lying outside its scope. That is what is done in allegorical and typological uses of the text, which have their own right to exist, but are not scholarly exegesis. If we are to understand proverbial literature, we need polished linguistic, literary and historical knowledge, but also sensitivity - an osmotic relationship of feeling our way into the text and rational analysis. So the 'Einfühlung' in minutiae taught us by Johann Gottfried Herder and Hermann Gunkel is indispensible.

26.Although these two methods have different substructures, they handle the textual details in the same way; cf. Loader (1985:62-66).

\section{Acknowledgements Competing interests}

The author declares that he has no financial or personal relationship(s) which may have inappropriately influenced him in writing this article.

\section{References}

Alter, R., 2010, The Wisdom Books: Job, Proverbs, and Ecclesiastes, W.W. Norton, New York. Clifford, R., 1999, Proverbs: A Commentary, Westminster John Knox, Louisville. (OTL). Delitzsch, F., 1873, Salomonisches Spruchbuch, Dörffling \& Franke, Leipzig. (Biblischer Commentar über das Alte Testament).

Fox, MV 2009, Proverbs 10-31: A New Translation with Introduction and Commentary, Yale University Press, New Haven. (The Anchor Bible 18B).

Gemser, B., 1963, Sprüche Salomos, J.C.B. Mohr, Tübingen. (HAT 16).

Loader, J.A., 1985, 'Chrysostom, Isaiah and the Antiochene View of Scripture', in C. Landman \& D.P. Whitelaw (eds.), Windows on Origins, FS J.A. Stoop, pp. 55-67, Unisa Publishers, Pretoria.

Loader, J.A., 2001, 'Zum Preis der Rechtfertigung Gottes im Alten Testament', Berliner Theologische Zeitschrift 18(1), 3-23.

Luchsinger, J., 2010, Poetik der alttestamentlichen Spruchweisheit, Kohlhammer Stuttgart. (Poetologische Studien zum Alten Testament 3)

McKane, W., 1977, Proverbs: A new Approach, SCM, London. (OTL).

Meinhold, A., 1991, Die Sprüche Teil 2: Sprüche Kapitel 16-31, Theologischer Verlag, Zürich. (ZBK 16/2).

Murphy, R.E, 1998, Proverbs, Thomas Nelson, Nashville. (WBC 22).

Oesterley, W.O.E., 1929, The Book of Proverbs, Methuen, London. (Westminster Commentaries)

Plöger, O., 1984, Sprüche Salomos (Proverbia), Neukirchener Verlag, NeukirchenVluyn. (BKAT 17).

Sæbø, M., 2012, Sprüche, Vandenhoeck \& Ruprecht, Göttingen. (ATD 16/1).

Scott, R.B.Y., 1981, Proverbs: Ecclesiastes: Introduction, Translation, and Notes, Doubleday, Garden City. (AB 18).

Toy, C.H., 1914, A Critical and Exegetical Commentary on the Book of Proverbs, T. \& T. Clark, Edinburgh. (ICC).

Waltke, B.K., 2005, The Book of Proverbs: Chapters 16-31, Wm. Eerdmans, Grand Rapids. (NICOT).

Williams, J.G., 1980, 'The Power of Form', Semeia 17, 35-58. 